\title{
THE NEW HUNGARIAN FIDUCIARY ASSET MANAGEMENT CONTRACT (TRUST) FROM COMPARATIVE ASPECT
}

\begin{abstract}
István Sándor*
The new Hungarian Civil Code introduced the fiduciary asset management contract within the scope of agency-type contracts. The regulation was drawn up on the basis of the model of the trust in English law and that of the Treuhand in German law. The article covers the most important elements of the Hungarian regulation, with special emphasis on comparison with the English trust and other regimes that adopted or worked out legal institutions similar to the trust.
\end{abstract}

INTRODUCTION

I. THE TRUST AND ITS AdOPTION IN CIVIL LAW SYSTEMS

II. THE CONCEPT OF THE FIDUCIARY ASSET MANAGEMENT CONTRACT IN THE

New Hungarian Civil Code. 604

III. GENERAL RULES OF THE FIDUCIARY ASSET MANAGEMENT CONTRACT604

A. Contractual Status of the Settlor ...............................................605

B. Rights and Obligations of the Trustee ...........................................606

C. Legal Status of the Trust Property ..............................................609

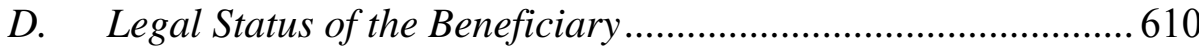

E. Legal Relationships between the Parties....................................610

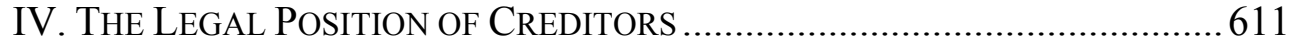

A. $\quad$ The Creditors of the Managed Property....................................612

B. $\quad$ Relationship between the Settlor and the Settlor's Creditors... 612

C. Legal Relationship between the Trustee and His Personal

D. Legal Relationship between the Beneficiary and His Creditors.....

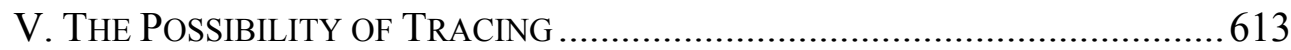

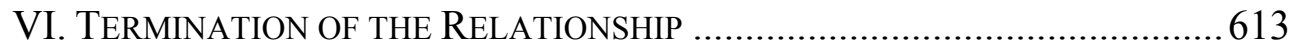

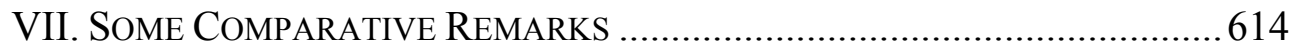

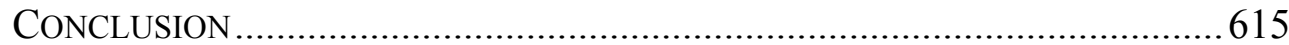

\footnotetext{
* Eötvös Loránd University, Faculty of Law, Department of Roman Law and Comparative Legal History, Hungary. Research fields: Roman Law, Legal History, Private Law and Comparative Law.
} 


\section{INTRODUCTION}

The aim of the study is to give a comparative law analysis of the trustlike device introduced in Hungary in 2014, with special emphasis on the decisive features of the regulations. The main question is, whether the Hungarian trust is suitable to substitute the Anglo-Saxon institution of the trust. The study takes into account such characteristics like the ownership of the trust fund, the property separation, the rights of the parties in the legal relationship, the possibility of tracing, the requirements for the trustee, the duration of the trust etc.

Part I shows the different forms of adoption of the English trust in civil law countries. Part II describes the background of the codification of fiduciary asset management contract in the Hungarian Civil Code and Part III gives a detailed introduction to the Hungarian regulation. Part IV analyzes the trust relationship from the creditors' aspects, while Part V deals with the rules of tracing and Part VI summarizes the possible ways of termination. Part VII contains the most important alterations of the Hungarian regulation from the English one.

\section{The TRUST AND Its Adoption In Civil LAW Systems}

The trust in common law is a unique legal institution. ${ }^{1}$ In this legal arrangement, the settlor vests the ownership of the property in the trustee, who manages this for the benefit of a third person, called the beneficiary. In this legal relationship, the trustee is obliged to handle the trust property separately from his own. The trustee holds legal title to the managed property, while the beneficiary has an equitable title. This structure is usually described as 'split ownership' because both the trustee and the beneficiary have some kind of ownership right to the same property at the same time. This special structure of ownership is not realised and accepted by the private laws of the Continental European legal systems. In the civil law systems, in the tradition of Roman law, ownership is recognised as an undivided right, which means that ownership of something at a given time is exclusive.

The trust gained relevant influence in common law countries and also in mixed jurisdictions. The trust encompasses and manages a wide range of both social and economic situations, potentially serving as an engine of the

\footnotetext{
1 "If we were asked what is the greatest and most distinctive achievement performed by Englishmen on the field of jurisprudence I cannot think that we should have any better answer to give than this, namely the development from century to century of the Trust idea.", FREDERICK WILLIAM MAITLAND, SELECTED Essays 129 (Cambridge, Cambridge University Press 1936).
} 
economy as well. That is the reason why strong efforts were made to adopt the trust in several civil law countries, or at least a trust-like device, which would fulfil the function of the trust. We may observe that the trust was adopted in the national laws of different countries in different periods. Scotland has a mixed legal system, although its property law is essentially based on civil law. The Scottish trust developed independently from the 17 th century. It is not based on the concept of divided ownership, although it was exposed to significant English influence. ${ }^{2}$ In the 19th century, the institution of the trust appeared in other legal systems, including South Africa, Québec, Louisiana, Sri Lanka. ${ }^{3}$ In the first half of the 20th century, the trust proliferated at a very rapid pace in Central and South American countries; most of these had adopted civil legal systems. Introduction of the trust followed in Colombia (1923), Panama (1925), Chile (1925), Mexico (1926), Bolivia (1928), Peru (1931), Costa Rica (1936), Venezuela and Nicaragua (1940), Guatemala (1946), Ecuador (1948), Honduras (1950). In these countries, the application of the trust (commonly called fideicomiso) was generally limited to the banking and financial system; regulation is based on the legal instrument of entailment. ${ }^{4}$ The trust was also introduced in Liechtenstein in the first half of the 20th century (1926), in the first European country not adopting the common law. The country applies mixed rules of the trust and the Treuhand, which evolved through legal practice. Japan was the first Asian country to regulate the institution of the trust in 1922. The next major date for adoption of the trust is the end of the 20th century, when countries with civil law systems also introduced this legal institution. South Korea introduced it in 1961, Russia in 1993 (significantly amending regulation two years later), Taiwan in 1996, China in 2001, France in 2007, Romania in 2011, the Czech Republic in 2014 and Hungary in 2013.

If we compare the different solutions adopted by legislators, we may group these countries on the basis of ownership criteria. There are countries where it is not necessary to transfer the ownership of the managed asset to the trustee - it is only a possibility. This is the concept applied, for example,

\footnotetext{
${ }^{2}$ T. B. SMith, Studies Critical And Comparative 22 (Edinburgh, W. Green \& Son Ltd. 1962).

${ }^{3}$ The adoption of the trust on a given level is mainly attributable to the fact that these countries are surrounded by countries with common law systems. See Tony Honoré, On Fitting Trusts into Civil Law Jurisdictions. Available at http://users.ox.ac.uk/ alls0079/chinatrusts2.PDF 1.

${ }^{4}$ L. S. Sánchez Vilella, The Problems of Trust Legislation in Civil Law Jurisdictions: The Law of Trusts in Puerto Rico, 19 Tulane Law Review 383 (1945) Ricardo J. Alfaro, The Trust and the Civil Law with Special Reference to Panama, 33(3-4) JOURNAL OF COMPARATIVE LEGISLATION AND INTERNATIONAL LAW 29 (1951).
} 
in Liechtenstein and Israel. ${ }^{5}$ There are countries, where the transfer of the legal title to the trustee is not allowed, for example in Russia ${ }^{6}$, or where this is not clearly defined, like in the Peoples' Republic of China. ${ }^{7}$ Unique regulation is applied in Québec, where managed property is linked to ownership without owner. ${ }^{8}$ Dutch regulation applies the institution of the bewind, which shows similar features to the trust. In this legal structure, the beneficiary is the legal owner of the property; the 'trustee', the manager, agent holds only management rights. ${ }^{9}$ In the practice of German civil law regimes, the Treuhand resembles the institution of the Anglo-Saxon trust. The difference is that the Treuhänder holds the legal title, while the beneficiary does not have any in rem right in relation to the managed assets. ${ }^{10}$

\footnotetext{
${ }^{5}$ Pursuant to Liechtensteiner PGR Art. 897, the settlor turns the trust property over ("zuwendet") to the trustee, that is, it is not essential to transfer ownership; it is sufficient to allow the trustee to dispose of the trust property in accordance with the contract (als selbständiger Rechtsträger). Kurt Moosmann, Der angelsächsische Trust und die Liechtensteinische Treuhänderschaft unter besonderer Berücksichtigung des wirtschaftlich Begünstigten. Eine rechtsvergleichende Studie mit Erkenntnissen für das Schweizer Treuhandrecht, Band 56 SCHWEIZER SCHRIFTEN ZUM BANKRECHT 224 (Zürich, Schulthess Polygraphischer Verlag AG 1999); Francesco A. Schurr, A Comparative Introduction to the Trust in the Principality of Liechtenstein, TRUSTS IN THE PRINCIPALITY OF LieChTENSTEIN AND Similar JuRisdictions 31 (Schurr, Francesco A ed., Zürich, St. Gallen, BadenBaden, Wien, Dike, Nomos Verlag, facultas.wuv 2014).

${ }^{6}$ Zlata E. Benevolenskaya, Trust Management as a Legal Form of Managing State Property in Russia, 35 REVIEW OF CENTRAL AND EAST EUROPEAN LAW 68 (2010).

7 “.... the settlor [...] entrusts (weituo) the rights in his property to the trustee and the trustee manages or disposes of such property in his own name in accordance with the wishes of the settlor for the benefit of the beneficiary or for a specified objective." In Lusina Ho, The Reception of Trust in Asia: Emerging Asian Principles of Trust? SingaPore Journal OF Legal StUdies 294 (2004); Rebecca Lee, Conceptualizing the Chinese Trust, 58(3) The InTERnATIONAL AND COMPARATIVE LAW Quarterly 659 (2009). Kenneth G. C. Reid, Conceptualising the Chinese Trust: Some Thoughts from Europe, University of Edinburgh School of Law, Working Paper Series No. 2011/06 (2011). Available at $\mathrm{http}: / / \mathrm{ssrn}$.com/abstract=1763826. 9 .

${ }^{8}$ The trust is regulated in the Civil Code of Quebec Title Six (Certain Patrimonies by Appropriation), in force as of 1 January 1994. Art. 1261 is clear in its definition: "The trust patrimony, consisting of the property transferred in trust, constitutes a patrimony by appropriation, autonomous and distinct from that of the settlor, trustee or beneficiary and in which none of them has any real right." Regulation in the new Czech civil code is in some ways very similar to this.

${ }^{9}$ Marius J. de Waal, Trust Law, in Elgar EnCYClOPEDIA OF COMPARATIVE Law 759 (Jan M. Smits ed., Cheltenham, Northampton, Edward Elgar 2006); H. L. E. Verhagen, Trusts in the Civil Law: Making Use of the Experience of 'Mixed' Jurisdictions, in Trusts IN MiXed Legal Systems 93, 106 (J. M. Milo-J. M. Smits ed., Nijmegen, Ars Aequi Libri 2001); Koppenol-Laforce-Kottenhagen, The Institution of the Trust and Dutch Law 139.

${ }^{10}$ The settlor only has the right to assert a claim by right in personam under the pactum fiduciae against the trustee for breach of the agreement. He does not, however, hold a right to assert claims against a third party acquiring the property, whether the transaction was concluded in good faith and gratuitously. See Eugen Dietrich Graue, Trust-Like Devices Under German Law, in W. A. WiLSON, Trusts and Trust-Like Devices, United Kingdom Comparative Law Series Vol. 5, 72 (London, Chameleon Press Limited 1981). Attila MenYhárd, Dologi Jog (Property Law) 477 (Budapest, Osiris Kiadó 2010). Dieter Liebich \& Kurt Mathews, Treuhand und Treuhänder in Recht und Wirtschaft, EIN HANDBUCH 23 (Herfle, Berlin, Verlag Neue Wirtschafts-Briefe 1983).
} 


\section{The ConcePt OF the Fiduciary Asset MANAGEMENT Contract In the New Hungarian Civil CODE}

The new Hungarian Civil Code (No. V of 2013) came into effect on 15th of March 2014. The Civil Code regulates the fiduciary asset management contract (in Hungarian: 'bizalmi vagyonkezelési szerződés') in Chapter XLII, within the scope of agency-type contracts. The concept of this new type of contract was drawn up on the basis of the model of the trust in English law and that of the Treuhand in German law. ${ }^{11}$ The introduction of fiduciary asset management on a legislative level is necessitated by strong, current demand in the economy. We have observed that several Hungarian investors chose legal regimes of other countries because the institution of the trust provided them with a better legal and economic solution. The Chief Codification Committee of the Civil Code codified fiduciary asset management under contract law, emphasising, however, the application of the legal instrument of the transfer of ownership, based on the trust-like model. Under the rules of the new Hungarian Civil Code, the fiduciary property management contract is an in personam legal instrument that implicitly carries substantial in rem effects. The new Hungarian Civil Code sets out a contractual arrangement and its validity is bound to a written contract. The regulation is of a general scope and several details are regulated in two separate pieces of legislation. Such details are regulated in Act XV of 2014 on Trustees and the Regulation of Their Activity, and in Government Decree No87/2014 (III. 20.) on certain rules concerning the financial security of fiduciary property management undertakings.

\section{GENERAL RulES OF THE FIDUCIARY ASSET MANAGEMENT CONTRACT}

As a general rule, regulation is dispositive; contracting is principally for consideration.

Pursuant to Section 6:310(1) of the new Hungarian Civil Code, under the fiduciary asset management contract, the trustee has the duty to manage the property transferred to his ownership by the settlor in his own name, for the benefit of the beneficiary, for which the settlor is obliged to pay a fee.

\footnotetext{
${ }^{11}$ LAJOS VÉKÁS (ED.), AZ ÚJ POLGÁRI TÖRVÉNYKÖNYV BIZOTTSÁGI JAVASLATA MAGYARÁZATOKKAL (Committee Proposal for the New Civil Code) 453 (Budapest, Complex Kiadó Jogi és Üzleti Tartalomszolgáltató Kft. 2012). Menyhárd qualifies the Hungarian regulation as an original, entirely new formation, which resembles the rules of the English trust much more than the German-Austrian Treuhand. Attila Menyhárd, A bizalmi vagyonkezelés szabályai az új Ptk.-ban (Rules of Fiduciary Property Management in the New Hungarian Civil Code), in TÁJÉKOZTATÓ FÜZETEK 251, Based on professional presentations held in the Legal Division of the MKIK 144 (Róbert Szakál ed., Budapest, MKIK Szolgáltató Nonprofit Kft. 2013).
} 
The managed asset can be things, rights and claims as well. ${ }^{12}$

If the settlor and trustee are one and the same person, fiduciary asset management is established by the irrevocable unilateral declaration of the settlor set out in a public instrument. A legal relationship of property management settled by testament is established by the trustee's acceptance of his appointment to such position, under the terms set out in the testament. Rules of the fiduciary property management contract are applied as necessary to fiduciary asset management established by a unilateral legal act. Rules of the agency contract are applicable as necessary to fiduciary asset management.

\section{A. Contractual Status of the Settlor}

Pursuant to the Civil Code, the rights of the settlor extend to the definition of the settled property and the appointment of the trustee. ${ }^{13}$ This, however, is a bilateral legal act, as it also requires the acceptance of appointment by the trustee. The settlor transfers ownership, rights and claims or other negotiable goods to the trustee, and the settlor issues a declaration as to the manner of the management of the property. In the legal relationship of property management, it is also possible to set out other conditions, such as its duration, which is maximum 50 years, terms, right of unilateral termination, remuneration of the trustee, appointment of additional trustees, regulation of the delegation of other agents, and the beneficiary's right to transfer. The settlor reserves the right to remove the trustee, appoint a new trustee, replace the beneficiary, modify given parts of the settlor's declaration, and to determine or modify the duration of property management.

The settlor may monitor the activity of the trustee falling within the scope of property management, but the costs of such monitoring are incurred by the settlor. It is a mandatory rule that the settlor may not instruct the trustee. The settlor, however, may remove the trustee from office at any time, and simultaneously appoint another trustee.

Section 6:311 of the new Hungarian Civil Code sets out provisions applicable to beneficiaries. As a general rule, the settlor designates the

\footnotetext{
${ }^{12}$ In connection with the regulation, see details in ISVTÁN SÁNDOR, A BIZALMI VAGYONKEZELÉS ÉS A TRUST. JOGTÖRTÉNETI ÉS ÖSSZEHASONLÍTÓ JOGI ELEMZÉS (FIDUCIARY PROPERTY MANAGEMENT AND THE Trust. Historical and Comparative ANALysis of Law) (Budapest, HVG-ORAC Lap- és Könyvkiadó Kft. 2014).

${ }^{13}$ In English law, three factors need to be defined with reasonable certainty for the establishment of a trust: the trust property, the beneficiary and the subject of the trust. ALASTAIR HUDSON, EQUITY AND TRUSTS 91 (Lond, New York, Routledge 2013).
} 
beneficiary, and the conditions that give rise to and terminate the rights of the beneficiary. The beneficiary may also be named by reference to a group of beneficiaries. The settlor may choose to pass on all or part of the trust property to himself, his successors or to designate third parties under certain circumstances, or after a certain period of time. The declaration of the trustee as exclusive beneficiary is void.

\section{B. Rights and Obligations of the Trustee}

Act XV of 2014 distinguishes professional and ad hoc asset management. An undertaking contracting on a regular basis for fiduciary property management at least twice annually, or for a property management fee in excess of one per cent of the value of the trust property on the date of the contract, or for any other financial gain, may carry out fiduciary asset management only in possession of the licence issued by the National Bank of Hungary prior to the start of such activity. The professional fiduciary asset managing company can be only a limited liability company or private limited company with a registered office in the territory of Hungary, or the branch - registered in Hungary-of an undertaking based in another contracting state of the Agreement on the European Economic Area.

The fiduciary asset management company may not carry out activity other than asset management, and its name must make reference to property management. The company must hold the licenses required for such activity. The fiduciary asset management company is required to fulfil strict staff and equipment requirements to receive the authorisation of the National Bank of Hungary.

The fiduciary asset management undertaking has the burden of proving that it duly performed its fiduciary asset management contracts in accordance with statutory requirements, for the utmost benefit of its client, in particular. The fiduciary asset management company is obliged to inform the future party to the contract of the risks defined by law prior to the conclusion of the property management contract. In addition, the fiduciary asset management company has the duty to provide information in writing, on a monthly basis. If no changes are made to the original information, it is sufficient to make reference to such fact in subsequent information. The fiduciary asset management company is required to maintain records on the fiduciary asset management relationships to support the traceability of fiduciary property management, administrative controls and administrative assessments of property.

Property management is essentially built on trust, particularly in 
relation to the selection of the trustee, that is, beyond their commercial relationship, the relationship between the principal and the trustee is governed predominantly by aspects of the agency contract, and less by a general contracting agreement. Under the contract, the trustee may not be the sole beneficiary. The settlor and the trustee, however, may be one and the same person. The trustee has the duty to provide information, manage the property as instructed in the declaration of the settlor, avoid conflicts of interest and manage the property separately from his own.

If the trustee is authorised to designate the beneficiary under the contract, the trustee has the right to determine the share of the beneficiary.

Due to stricter requirements arising from the fiduciary nature of the legal relationship, the trustee has the duty to act in utmost consideration of the interests of the beneficiary. The trustee has the duty to protect the trust property against foreseeable risks in a commercially reasonable manner.

The management of the property includes the exercise of rights arising from ownership, other rights and claims transferred to the trustee, and the fulfilment of obligations arising there from. The trustee may dispose of the assets belonging to the trust property under the conditions and within the limits sets out in the contract. If the trustee breaches his above obligations and illicitly transfers assets belonging to the trust property to a third party, the settlor and beneficiary have the right to reclaim these for the benefit of the trust property, if the third party did not purchase the assets in good faith or for consideration. This rule is applicable as necessary to the illicit encumbrance of the trust property.

The trustee has a duty to keep confidential any fact, information and other data he becomes aware of during his appointment as trustee or in relation thereto. Such obligation is without prejudice to the establishment of the trusteeship and remains in effect after the termination of fiduciary property management. The settlor and his successors may grant exemption from the confidentiality obligation.

The trustee has the duty to inform the settlor or the beneficiary of the trust property upon their request. Such information must cover, in particular, the actual and foreseeable increase in the trust property, the particular assets of the trust property and their value, and commitments charged to the trust property. Upon request, the trustee has the duty to account for the trust property, and settle accounts with the settlor and beneficiary. Costs incurred in connection with the provision of information and the payment of invoices is borne by the settlor and beneficiary.

The trustee is liable toward the settlor and beneficiary for the breach of his obligations in accordance with general rules of liability for damages. If 
the trustee carries out his duties gratuitously, rules of liability for damages are applicable to his breach of gratuitous contracts. The settlor and beneficiary may claim the management of any financial gain as part of the trust property, which was realised through the trustee's breach of his obligations arising from property management.

If the trustee carries out his duties gratuitously, he may claim the reimbursement of his regular costs. The trustee may satisfy his claims for the payment of his fees and reasonable costs, and other claims arising from property management directly from the trust property.

The trustee is liable for the fulfilment of the undertaken obligations with the trust property. The trustee assumes unlimited liability with his own property for the satisfaction of claims arising from commitments charged to the trust property, if these cannot be satisfied from the trust property, and the other party was not and could not have been aware that the commitments of the trustee exceed the limits of the trust property.

If the settlor appoints several trustees, the actions and decisions of the trustees are taken jointly. If the trustees are also liable with their own property for their commitments, they assume joint and several liability for joint decisions toward third parties. Several trustees assume joint and several liability toward the settlor and beneficiary for the breach of obligations arising from fiduciary property management.

If the settlor dies or ceases without a successor, and there are no other settlors to the trust property, the court may recall the trustee from his office upon request of the beneficiary, and simultaneously appoint another trustee if the trustee seriously breached the contract. Several beneficiaries may exercise such right jointly, provided any of them may request the court to terminate the appointment of the trustee and to appoint a new trustee. The court may not appoint a person as trustee, against whom all beneficiaries object.

The rights of the trustee are governed by the legal instrument applicable to property management and rules set out in the given property management contract. As a general rule, rights of use and disposition are also conferred on the trustee in the case of property management contracts, that is, the trustee has the right to

- use and operate the managed thing,

- possess the managed thing, resort to protection of possession under the appropriate title,

- enjoy, that is, utilise the managed thing either by himself, or with the collaboration of a subcontractor or agent, if he is authorised to employ such third parties under the property management contract. 
- right of alienation (e.g. in the case of portfolio-type asset management),

- right of encumbrance (establishment of e.g. lien on assets belonging to the property),

- right of destruction, or rather, right of processing and use (e.g. en entire plant is entrusted, together with its raw materials, and these are processed in the regular manufacturing process).

The issue of rights conferred on the trustee raises an interesting question in relation to the management of company shares. In this case, the trustee may be entitled to exercise membership or shareholder rights.

Due diligence is generally applicable to property management contracts. Rules pertaining to remuneration, however, are not necessarily subject to this approach. If, in the process of utilising the trust property, the parties do not set out the amount of yields at the time of contracting, but only the diligence of the trustee, the trustee is required to follow due diligence under the contract to ensure the satisfactory performance of the contract. If, however, the fiduciary asset management contract sets out specific yields and profits, remuneration may be linked to these. Under the asset management contract, the trustee may not be instructed to preserve the assets, but must ensure that the property entrusted to him preserves its value. In such cases, the asset management contract fulfils the function of consignment or portfolio management. Obviously, these three elements may be combined in the property management contract; the trustee is obliged to follow due diligence, he receives separate remuneration when realising a certain level of profits, and, as the case may be, he may sell the entrusted assets on the basis of general or single authorisation.

The remuneration of the trustee may be implemented under different schemes.

\section{Legal Status of the Trust Property}

Section 6:312 of the Civil Code sets out rules on the separation of property. The trust property constitutes property separate from the trustee's own property and other property managed by him, which the trustee is obliged to register separately. The parties' derogation from this rule is void. Assets registered as property managed separately from the trustee's own property and other property managed by him are deemed to fall within the scope of trust property until proven otherwise. Any assets substituting the managed assets, insurance indemnities, damages or other value, and profits thereon, constitute part of the trust property, whether registered or not. 
Assets not registered by the trustee as comprising part of the trust property are deemed to be the private property of the trustee until proven otherwise.

The spouse, life partner, personal creditors of the trustee, and creditors of other properties managed by the trustee may not lay claim to the assets of the trust property. The trust property does not constitute part of the trustee's inheritance. The beneficiary and the settlor may take action against the spouse, life partner, personal creditors of the trustee, and creditors of other properties managed by the trustee, to secure the separation of the trust property.

The indirect object of the asset management contract may be securities, company shareholdings, real property, personal property, and other rights and claims. Asset management relating to securities essentially comprises a special area of law applicable to securities traders, which we are not exploring in depth.

The management of company shareholdings is a contractual arrangement essentially applicable to companies with share capital, including quotas in limited liability companies and shares in companies limited by shares. Obviously, this is feasible in any case, where the transfer of company shares is possible.

\section{Legal Status of the Beneficiary}

Under an important rule regulating the rights of the beneficiary, the beneficiary may claim the distribution of the trust property and its profits from the trustee under the contract. The creditors of the beneficiary may assert claims for the assets of the beneficiary, when the distribution of such assets or the profits thereon to the beneficiary is due.

The beneficiary may also monitor the activity of the trustee falling within the scope of asset management; the costs thereof are incurred by the beneficiary. The beneficiary does not have the right to instruct the trustee, either.

\section{E. Legal Relationships between the Parties}

The relationship between the settlor and trustee (also) constitutes the basis of other legal relationships. This is where the trustee's responsibilities and fiduciary obligations, his level of diligence and loyalty are defined. The Civil Code regulates the settlor's monitoring right, right of exemption from confidentiality, right to recall, but expressly prohibits him from issuing instructions. With respect to loyalty, the duty of the trustee not to compete is of central relevance. The regulation of rules on the use of the trust property 
is also important.

The beneficiary has the right to legally enforce the fulfilment of the trustee's obligations. Within this context, it is necessary to examine rights exercised by the beneficiary against the obligor in the case of civil third party beneficiary contracts. The beneficiary has the right claim the trust property and profits thereon, to receive information, while the trustee is entitled to remuneration and the reimbursement of his costs. Similarly to the settlor, the beneficiary does not have the right to instruct the trustee.

There is no legal relationship between the settlor and the beneficiary. If the settlor is also a beneficiary, obviously his capacity is relevant in terms of exercising particular rights.

In respect of the relationship between several settlors, it is necessary to determine whether they assume joint or joint and several liabilities. This is not regulated by the Civil Code, thus general rules are applicable.

Joint and several liabilities under Anglo-Saxon law are governing in relation to several trustees. Among the rules of succession, the new Hungarian Civil Code adopts the right of survivorship of the other trustees in relation to the ownership of the ceased trustee.

The relationship between several beneficiaries is principally determined by the contract concluded between the settlor and the trustee. However, the limited possibility of pupillary substitution should be taken into account in relation to succession after the death of the beneficiary.

The rules of the Civil Code do not preclude the transfer of the trust property and the profits thereon from one beneficiary to another upon the fulfilment of certain conditions or after a given time.

\section{The Legal Position OF CREDITORS}

In terms of liability, the Civil Code does not allow the creditors of the settlor and trustee to assert claims for the trust property. The creditors of the beneficiary, however, may apply for execution of the property, notwithstanding that the distribution of the managed assets and profits thereon to the beneficiary is not due yet. This rule is modified by Act XV of 2014 to the extent that the creditors of the settlor may terminate the asset management contract if the execution procedure launched against the settlor is unsuccessful, or does not produce any results within a foreseeable time. I wish to note that this rule is already drawing heavy criticism in Hungarian legal literature, as it ignores differences in time between the exercise of the right of termination and the insolvency of the settlor.

As a general rule, the trustee is liable with the trust property for the 
fulfilment of his obligations. However, the trustee assumes unlimited liability with his own property toward third parties if their claims cannot be satisfied from the trust property, and the third parties were not and could not have been aware that the commitments of the trustee exceed the limits of the trust property.

\section{A. The Creditors of the Managed Property}

If the trustee conducts business with the managed property, and third parties' claim arise from it which cannot be covered from the trust property, then the creditors, as a general rule, may not seek satisfaction of their claims against the trustee. The trustee, however, exceptionally assumes unlimited liability with all of his own property if claims asserted for the trust property cannot be satisfied, and the other party was not and could not have been aware that the commitments of the trustee exceed the limits of the trust property.

\section{B. Relationship between the Settlor and the Settlor's Creditors}

As a general rule, the creditors of the settlor may not lay claim to the trust property, unless the settlor is also a beneficiary. In respect of the contract between the settlor and the trustee, the creditors of the settlor may assert claims in accordance with the modern rules of actio Pauliana, under the general rules of the law of obligations. In addition, the aforementioned Act XV of 2014 also allowed the termination of the asset management contract in the execution procedure launched against the settlor.

\section{Legal Relationship between the Trustee and His Personal Creditors}

Pursuant to regulation in the Civil Code, which corresponds to the rules of common law, in the event of the trustee's insolvency, the creditors of the trustee may not lay claim to the trust property. This rule is also applicable to the spouse, partner and successors of the trustee. This regulation provides asset partitioning for the trustee which resembles to the Anglo-Saxon trust rules.

\section{Legal Relationship between the Beneficiary and His Creditors}

The creditors of the beneficiary clearly have the right to take action against the trustee, quasi under the legal title of the beneficiary. This is possible under the Civil Code if the right of the beneficiary is due. 
It is difficult to determine the claim of the beneficiary's creditors in relation to the beneficiary's claim in the trust property, if the trustee holds discretionary power with respect to the management of the property, because the claim of the beneficiary is also uncertain and unascertainable in such a case.

\section{THE PossiBILITY OF TRACING}

The settlor and the beneficiary have the right to take action against third parties to whom the trustee transferred property in breach of the asset management contract, gratuitously or in bad faith. Such regulation essentially corresponds to the rules of common law tracing in English law.

In the case of a third party purchasing property gratuitously or in breach of the requirement of good faith, the Hungarian Civil Code does not provide any guidelines as to whether the settlor or the beneficiary may take action if the property is mixed with the property of the purchaser, its object changes, or the property is transferred further to other persons. Under the principle of equitable tracing in English law, this is possible under certain circumstances. Case law will eventually demonstrate the specific cases in which the claims of the settlor and beneficiary can be enforced.

\section{TERMINATION OF THE RELATIONSHIP}

The fiduciary asset management relationship is terminated

- if no trust property is left;

- three months after resignation, if the trustee resigns from his position;

- on the termination date of the trustee's engagement, if there is no trustee to manage the trust property for over three months;

- on the date of the settlor's death, if he was the sole beneficiary.

When resigning, the trustee has the duty to act in utmost consideration of the interests of the beneficiary. Under a mandatory rule, the legal relationship of fiduciary property management established indefinitely or for a fixed period of more than 50 years is terminated after 50 years.

Fiduciary asset management is not terminated if the settlor becomes successor to the trustee. Fiduciary asset management, however, is not terminated upon the death or cessation of the settlor, trustee or beneficiary.

Upon termination of fiduciary asset management, the trustee remains subject to the accounting and information obligation imposed under effective fiduciary asset management. If the termination of fiduciary asset management poses a risk to the trust property, until the settlement of accounts, the trustee has the duty to take the necessary measures required 
under the fiduciary asset management.

Upon termination of his appointment, the trustee has the duty to pass on the trust property to another or new trustee appointed by the settlor, otherwise to the settlor. If the trustee ceases without successor, the trust property is passed on to another or new trustee appointed by the settlor, otherwise it is transferred back to the settlor upon cessation of the trustee. The obligations encumbering the trust property are passed on to another or new trustee as part of the trust property, otherwise to the settlor. In case of more than one settlor, the settlors become entitled to the trust property transferred back to them in proportion of their contribution to the trust property, and they assume the obligations transferred back to them as part of the trust property in the same proportion; they assume joint and several liabilities toward creditors of the trust property. If the contract provides for the distribution of the property in the form of succession in the position of the trustee, the rules defined above are appropriately applicable to the transfer of rights and obligations to the successor.

\section{SOME COMPARATIVE REMARKS}

We describe below the main areas where Hungarian fiduciary asset management varies from the Anglo-Saxon institution of the trust.

Under the new Hungarian Civil Code, the fiduciary asset management contract mostly resembles the express trust. Conditions give rise to a resulting trust only in exceptional cases [6:Sec. 321(3)], while the constructive trust and charitable trust are not regulated. This is, to a certain extent, understandable, as under Hungarian private law, these legal situations are regulated with the institutions of unjust enrichment, foundations and public donations.

The fiduciary asset management contract must be made in writing, while the Anglo-Saxon trust may be created orally or by implied conduct. In view of the fact that fiduciary asset management is a new legal instrument in Hungarian law, we believe it is reasonable that the contract is bound to a written form to avoid any legal uncertainties.

The new Hungarian Civil Code does not set out expressis verbis that the settlor has the right to revoke fiduciary asset management, while in Anglo-Saxon Law, the settlor retains this option during his lifetime, if he laid this down in the deed of trust. We should be aware, however, that the rules of agency provide background regulation to the fiduciary asset management contract, granting broad discretionary termination rights to the principal. 
Under the new Hungarian Civil Code, as a general rule, fiduciary asset management is a contract for consideration, while Anglo-Saxon law presumes gratuity, unless provided otherwise. Since fiduciary asset management was drawn up according to the model of the agency contract in Hungarian law, this may be the reason for its regulation as principally a contract for consideration.

Under the new Hungarian Civil Code, the fiduciary asset management contract has a maximum duration of 50 years. A time limit is also applied in English law, with the exception of the charitable trust. International trends, however, increasingly suggest a loosening and elimination of time limits.

According to the principle derived from the Saunders v. Vautier case ${ }^{14}$, the beneficiary is entitled to the distribution of the trust property if he is of legal age and does not breach the interests of other beneficiaries. This rule is worth considering for possible application in Hungarian legal practice.

With regard to the fiduciary asset management contract under the new Hungarian Civil Code, legal practice will likely resolve many issues currently not regulated by statutory rules. Such issues include the settlor's option of modifying the rules of the contract if this is necessary in the interest of the beneficiary. The definition of the eligibility conditions applicable to the position of trustee also raises several questions. The trustee is obliged to carry out his duties in person, that is, additional requirements may be applied to him through the implementing regulations of the new Hungarian Civil Code.

\section{CONCLUSION}

On the basis of the research we have to come to the conclusion that the Hungarian regulation of fiduciary asset management contract is mainly convenient to the Anglo-Saxon trust. We have to emphasize that the Hungarian trust regulations functionally are in accordance with the English law principles. We can find high-level regulation of asset partitioning, the trustee's office and the rules of tracing. Some critics may be expressed on the obligatory registration of the trust, which can be explained by chariness of the legislators. Overall the Hungarian trust can fill out the main functions of the English trust in the economy.

The author supposes that the Hungarian trust-like legal instrument will gain ground step by step in the near future, which will contribute to the economy and the international business relationships of Hungary as well.

\footnotetext{
${ }^{14}$ Saunders v. Vautier [(1841), Cr. \& Ph. 240.; 4 Beav 115].
} 